Marwah: Jurnal Perempuan, Agama dan Jender (p-ISSN: 1412-6095 | e-ISSN: 2407-1587)

Vol. 17, No. 1, 2018, Hal. $31-41$

\title{
HUBUNGAN KEMATANGAN EMOSI DENGAN KEPUASAN PERNIKAHAN PADA ISTRI YANG BEKERJA
}

\author{
RESA VONIKA \\ UIN Sultan Syarif Kasim Riau, Indonesia \\ reshavonika@ymail.com \\ RICCA ANGREINI MUNTHE \\ UIN Sultan Syarif Kasim Riau, Indonesia \\ ricca.angreini@,uin-suska.ac.id
}

\begin{abstract}
This article aims to find out the relationship between emotional maturity and marital satisfaction with a working wife. Subjects in this study were 83 working women who lived in Tuah Karya Village, Tampan District. The technique of determining subjects using accidental sampling. This study used the ENRICH Marital Satisfaction (EMS) marriage satisfaction scale proposed by Olson \& Fowers and the emotional maturity scale prepared by the author with 26 items. This scale is based on the characteristics of emotional maturity proposed by Walgito. The data analysis technique used in this study is Pearson's Product Moment correlation calculation technique. The results of this study indicate that there is a significant relationship between emotional maturity with marital satisfaction in the working wife. However, the contribution of emotional maturity to marital satisfaction for wives who work is only $9.8 \%$.
\end{abstract}

Keywords: marriage satisfaction, emotional maturity, working wife

\begin{abstract}
ABSTRAK
Artikel ini bertujuan untuk mengetabui bubungan kematangan emosi dengan kepuasan pernikahan pada istri yang bekerja. Subjek pada penelitian ini adalah 83 orang wanita bekerja yang bertempat tinggal di Kelurahan Tuah Karya, Kecamatan Tampan. Teknik penentuan subjek menggunakan accidental sampling. Penelitian ini menggunakan skala kepuasan pernikahan ENRICH Marital Satisfaction (EMS) yang dikemukakan oleh Olson \& Fowers dan skala kematangan emosi yang disusun sendiri oleh penulis dengan jumlah 26 item. Skala ini berdasarkan karakteristik-karakteristik kematangan emosi yang dikemukakan oleh Walgito. Teknik analisis data yang digunakan dalam penelitian ini yaitu teknike perhitungan korelasi Product Moment oleh Pearson. Hasil penelitian ini menunjukkean terdapat bubungan yang signifikan antara kematangan emosi dengan kepuasan pernikahan pada istri yang bekerja. Namun, kontribusi kematangan emosi terhadap kepuasan pernikahan pada istri yang bekerja hanya 9,8\%.
\end{abstract}

Kata Kunci: kepuasan pernikahan, kematangan emosi, istri yang bekerja

\section{A. PENDAHULUAN}

Memilih pasangan hidup dan menikah merupakan salah satu tugas perkembangan yang penting dimasa dewasa. Seseorang memutuskan untuk menikah dengan tujuan terbentuknya keluarga yang bahagia dengan terciptanya kepuasan dalam hubungan yang 
dijalani. Pernikahan dikatakan bahagia apabila dalam keluarga tidak terjadi pertengkaranpertengkaran, sehingga keluarga dapat berjalan dengan lurus tanpa adanya goncangangoncangan yang berarti (Walgito, 2004). Artinya, pasangan yang menikah mampu mengatasi permasalahan yang terjadi dalam rumah tangganya, sehingga tidak menimbulkan pertengkaran yang berkepanjangan.

Pasangan yang menikah memiliki tanggung jawab yang berbeda dalam keluarga. Laki-laki sebagai suami yang merupakan kepala rumah tangga bertanggung jawab untuk bekerja mencari nafkah, sedangkan perempuan sebagai istri bertanggung jawab dalam melayani suami dan anak serta mengerjakan perkerjaan rumah tangga. Namun, berkat pendidikan dan perkembangan dunia pekerjaan yang semakin maju membuat istri memilki kesempatan untuk mengembangkan karir dan pekerjaannya, sehingga banyak dijumpai istri yang bekerja di luar rumah. Selain itu, tuntutan ekonomi juga menjadi pendorong bagi kaum wanita untuk memasuki dunia kerja (Stefani, Pudjibudojo \& Prihanto, 2000).

Menjadi istri yang bekerja bukanlah pekerjaan yang mudah. Ananda (2013) memaparkan, banyak persoalan yang dialami oleh wanita yang bekerja seperti bagaimana mengatur waktu dengan suami dan anak hingga mengurus tugas-tugas rumah tangga dengan baik. Ada yang dapat menikmati peran gandanya dan ada juga yang merasa kesulitan hingga akhirnya persoalan rumit kian berkembang dalam kehidupan rumah tangga.

Menjadi istri yang bekerja harus siap menerima kenyatataan seperti, jumlah jam kerja penuh waktu membuat waktu yang dimiliki istri banyak dihabiskan untuk bekerja. Istri merasa kelelahan saat berada di rumah dan rentan terhadap munculnya emosi negatif. Ratnawati (2008) menambahkan, istri bekerja akan mengalami konflik emosional yang berupa perasaan bersalah, stress, kelelahan, ketidakberdayaan, kecemasan, kemarahan, kebingungan dan keharuan. Selain itu, wanita bekerja menjalani dua peran yang berbeda yang masing-masing peran memiliki tuntutannya. Adapun tuntutan dari pekerjaan berkaitan dengan tekanan yang berasal dari beban kerja yang berlebihan dan desakan waktu, seperti pekerjaan yang menumpuk yang harus diselesaikan pada waktu yang bersamaan, sedangkan tuntutan dari keluarga berkaitan dengan waktu yang dibutuhkan untuk menangani tugas-tugas rumah tangga dan menjaga anak yang ditentukan oleh besarnya keluarga, komposisi keluarga dan jumlah anggota keluarga yang memilki ketergantungan terhadap anggota lainnya (Yang, Chen, Choi \& Zou, 2000). 
Beban dan tekanan yang dirasakan istri bekerja berdampak pada relasi dengan suami. Kondisi tersebut dapat membuat istri yang bekerja menjadi rentan terhadap emosi negatif. Misalnya, ketika berhadapan dengan suami istri menjadi mudah marah dan kesal, baginya ada saja hal yang menyinggung perasaannya. Hal tersebut dapat memunculkan perasaan tidak dimengerti, tidak diperthatikan dan perasaan tidak nyaman untuk berkumpul, bercerita atau berbagi keluh kesah bersama pasangan sehingga istri merasakan tidak puas dengan pernikhannya.

Olson, Defrain dan Skogrand (2010) memaparkan, kepuasan pernikahan adalah perasaan yang bersifat subjektif dari pasangan suami istri mengenai perasaan bahagia, puas dan menyenangkan terhadap pernikahan secara menyeluruh. Kepuasan pernikahan dapat tercipta apabila terpenuhinya kebutuhan, harapan dan keinginan suami istri dalam pernikahan. Seseorang yang merasakan kepuasan pernikahan terlihat dari, kenyamanan dalam berkomunikasi, aktivitas waktu luang yang dilakukan bersama pasangan, masalah yang terselesaikan, hubungan dengan keluarga berjalan dengan baik, kenyamanan dalam berhubungan dengan keluarga dan teman, kesamaan peran, dan memahami kepribadian pasangan (Olson \& Fower, 1989). Kepuasan pernikahan adalah sesuatu yang dicari dan diharapkan oleh setiap pasangan yang menikah.

Rahmiati (2010) menjelaskan, pasangan dari pernikahan yang puas memiliki kesehatan mental dan fisik daripada pasangan yang tidak merasa puas dengan pernikahannya. Istri bekerja akan dapat merasakan kepuasan pernikahan apabila memiliki kematangan emosi. Individu yang matang secara emosional memiliki kemampuan untuk menjalin dan mempertahankan hubungan personal (Blood \& Blood dalam Rismawati 2008) dan ini akan menciptakan jalinan kasih mesra yang lama dengan kedamaian bersama pasangan sehingga berpengaruh pada terciptanya kepuasan pernikahan (Davidof, 1991). Wanita yang memiliki kematangan emosi dapat dilihat dari kemampuan dalam mempertahankan keutuhan rumah tangga, dapat meminimalisir konflik yang terjadi akibat ketidakseimbangan dalam menjalani tuntutan pekerjaan dan keluarga, dapat menjalani tanggung jawab sebagai ibu dan istri, dapat mengontrol emosi dengan baik ketika mengalami masalah di tempat kerja agar tidak terbawa ke rumah.

Berdasarkan uraian di atas, penulis tertarik untuk meneliti hubungan kematangan emosi dengan kepuasan pernikahan pada wanita bekerja. 


\section{B. TINJAUAN PUSTAKA}

Pernikahan merupakan cara untuk memperoleh hubungan seksual dan keintiman. Pasangan suami istri yang menikah tentu menginginkan pernikahan yang bertahan seumur hidup dan memperoleh kepuasan dalam pernikahannya. Kepuasan pernikahan merupakan perasaan yang bersifat subjektif dari pasangan suami istri mengenai perasaan bahagia, puas dan menyenangkan terhadap pernikahannya secara menyeluruh (Olson dkk, 2010).

Kepuasan pernikahan tergambar dari perasaan nyaman terhadap komunikasi yang djalani bersama pasangan, perasaan senang terhadap kegiatan waktu luang yang dilakukan bersama pasangan, penerapan nilai-nilai agama dalam keluarga, perasaan puas terhadap penyelesaian masalah, nyaman bersama pasangan dan senang akan peran yang dijalani dalam keluarga (Olson \& Fower 1989). Berbagai cara dilakukan oleh pasangan suami istri agar tercipta kepuasan pernikahan. Namun, untuk mencapai kepuasan pernikahan tidaklah mudah terutama pada wanita bekerja. Beban dan tekanan kerja membuat wanita rentan akan munculnya emosi negatif sehingga hal tersebut mempengaruh relasi wanita dengan pasangan dan berdampak pada kepuasan pernikahan. Hal ini sesuai dengan pernyataan Paputungan (2013), wanita yang bekerja secara full time di luar rumah berdampak pada berkurangnya kepuasan pernikahan, namun berbeda dengan pasangan yang mampu menjaga keintiman secara emosional seperti menjaga kemesraan bersama pasangan, akan mampu mendukung kepuasan pernikahan mereka.

Selain itu, jumlah jam kerja penuh wantu membuat banyaknya energi yang dimiliki wanita habis untuk mengerjakan tugas kantor sehingga mengakibatkan wanita pada saat di rumah dalam kondisi lelah. Keluarga hanya mendapatkan sisa-sisa tenaga dengan kondisi emosi yang buruk yang membuat wanita menjadi mudah marah, sedih, merasa tidak berguna, suka menyendiri, dan stres. Padahal pada saat wanita berada di rumah pasangan menginginkan kondisi yang penuh ketenangan, kedamaian, kehangatan dan penuh pengertian sebagai tempat berbagi berbagai permasalahan kehidupan. Akibatnya hal tersebut memicu perselisihan dalam rumah tangga wanita bekerja yang berakibat pada komunikasi yang buruk, hubungan yang tidak akrab dan mesra, masalah yang tidak terselesaikan, hubungan dengan keluarga tidak baik dan peran yang tidak berjalan dengan sempurna.

Perselisihan yang ditandai dengan kemarahan, kekesalan, kejenuhan, kebencian, tidak dapat menerima dan memahami pasangan serta ketegangan adalah merupakan penggambaran emosi yang tidak matang. Kematangan emosi memnuhi kriteria dapat 
menerima bak keadan dirnya maupun orang lain, tidkak bersifat implusif, dapat mengontrol emosi dan ekspresnya dengan baik, dapat berpkr objektif, dan mempunyai tanggung jawab. Nurpratiwi (2010) menjelasakan bahwa kematangan emosi berhubungan dengan kepuasan pernikahan. Emosi yang tidak ditanggap secara tepat akan menurunkan kepuasan pernikahan pada wanita bekerja. Kematangan emosi dapat menciptakan jalinan kasih mesra dan kedamaian bersama pasangan yang berdampak pada terciptanya kepuasan pernikahan (Davidoff, 1991).

Walgito (2004), kematangan emosi dapat diartikan sebagai kemampuan individu untuk mengadakan tanggapan-tanggapan emosi secara matang dan mampu mengontrol serta mengendalikan emosinya sehingga menunjukkan suatu kesiapan dalam bertindak. Mengendalikan emosi itu diperlukan karena emosi mempunyai kemampuan untuk mengkomunikasikan diri kepada orang lain, agar pergaulan sehari-hari dapat berjalan dengan lancar dan dapat mengikuti kehidupan yang tentram (Estuti, 2013). Pada kenyataaannya, wanita cenderung menunjukkan emosi yang tidak tepat pada saat berhadapan bersama pasangan selepas bekerja seperti melampiaskan rasa marah akibat stres di tempat kerja kepada pasangan, tidak dapat bertoleransi pada kesalahan pasangan, murung, mudah tersinggung dan ingin selalu dimengerti. Hal tersebut memperngaruhi hubungan berssama pasangan.

Wanita yang memiliki kematangan emosi akan dapat mengendalikan emosinya sehingga pada saat dihadapi suatu permasalahan wanita akan mudah menemukan solusi dalam penyelesaian masalah yang timbul dalam kehidupan pernikahannya. Hal ini sesuai dengan aspek kepuasan pernikahan (Olson \& Fower, 1989) yang ditandai dengan kemampuan menyelesaikan masalah. Jika wanita mampu menyelesaikan permasalahan dalam kehidupan pernikahannya dengan emosi yang matang, maka wanita akan merasa tentram, nyaman dan mesra sehingga kepuasan pernikahan dapat dirasakan.

Berdasarkan pemaparan di atas, maka hipotesis yang diajukan dalam penelitian ini adalah ada hubungan kematangan emosi dengan kepuasan pernikahan pada wanita bekerja. Artinya, semakin tinggi kematangan emosi pada wanita bekerja maka semakin tinggi kepuasan pernikahannya. Sebaliknya, semakin rendah kematangan emosi pada wanita bekerja maka semakin rendah kepuasan pernikahan. 


\section{METODE PENELITIAN}

Pada penelitian ini peniliti menggunakan pendekatan kuantitatif. Subjek pada penelitian ini adalah 83 orang wanita bekerja yang bertempat tinggal di Kelurahan Tuah Karya, Kecamatan Tampan. Teknik penentuan subjek menggunakan accidental sampling. Penelitian ini menggunakan skala kepuasan pernikahan ENRICH Marital Satisfaction (EMS) yang dikemukakan oleh Olson \& Fowers (1993) yang berjumlah 15 aitem. Kematangan emosi dinilai menggunakan skala kematangan emosi yang disusun sendiri oleh penulis dengan jumlah 26 item. Skala ini berdasarkan karakteristik-karakteristik kematangan emosi yang dikemukakan oleh Walgito (2004). Adapun karakteristikkarakteristiknya adalah penerimaan diri dan orang lain, tidak bersifat implusif, pengendalian diri, mampu berpikir objektif, dan bertanggung jawab.

Teknik analisis data yang digunakan dalam penelitian ini yaitu teknik perhitungan korelasi Product Moment oleh Pearson, yang bertujuan untuk mengetahui hubungan antara kematangan emosi dengan kepuasan pernikahan (Arikunto, 2010). Analisis yang dilakukan menggunakan bantuan komputerisasi dengan aplikasi program SPSS-Statistical Product and Service Solutions 16.0 for Windows.

\section{HASIL DAN PEMBAHASAN}

Subjek pada penelitian ini lebih banyak berada pada usia dewasa awal yaitu berjumlah 51 orang $(61,4 \%)$ dan yang lebih sedikit berada pada usia dewasa madya, yaitu 32 orang $(38,6 \%)$. subjek pada penelitian ini lebih banyak yang berada pada usia pernikahan 1-10 tahun, yaitu berjumlah 39 orang (47\%) dan lebih sedikit berada pada usia 31-40 tahun, yaitu berjumlah 1 orang $(1,2 \%)$. Selain itu, subjek yang berada pada usia pernikahan 11-20 tahun berjumlah 27 orang (32,5\%), subjek pada usia pernikahan 21-30 tahun berjumlah 16 orang $(19,3 \%)$.

\section{Uji Asumsi}

Uji asumsi dalam penelitian ini adalah normalitas dan linieritas. uji normalitas yang digunakan adalah dengan melihat nilai signifikansi (Asymp Sig) pada uji One-Sample Kolmogorov-Swirnov Test. Data disebut normal jika $\mathrm{p}>0,05$. untuk variabel kematangan emosi adalah sebesar 0,862 ( $>$ > 0,05), artinya sebaran data kematangan emosi berdistribusi normal. Nilai signifikansi $(p)$ variabel kepuasan pernikahan adalah sebesar 0,340 ( $p>0,05)$ artinya, sebaran data kepuasan pernikahan berdistribusi normal. Uji linearitas bertujuan untuk melihat arah, bentuk dan kekuatan hubungan antara dua variabel. Uji linearitas yang 
digunakan dalam penelitian ini adalah uji $\mathrm{F}$, data akan dikatakan linear dengan ketentuan signifikasinya lebih kecil dari 0,05 ( $\mathrm{p}<0,05)$. Berdasarkan hasil uji linearitas pada variabel kematangan emosi dan kepuasan pernikahan diketahui nilai $\mathrm{F}$ sebesar 9,401 dengan signifikansi 0,003 ( $<<0,05)$, dengan begitu data tersebut adalah linear. Berdasarkan curve fit diketahui besar koefisien determinasi adalah Rsq = 0,098. Artinya, variabel kematangan emosi memiliki kontribusi sebesar 9,8\% terhadap kepuasan pernikahan sedangkan 8,2\% dipengaruhi oleh variabel lain.

\section{Uji Hipotesis}

Pada penelitian ini dilakukan uji hipotesis yang bertujuan untuk mengetahui taraf signifikansi hubungan kematangan emosi dengan kepuasan pernikahan. Adapun ketentuan diterima atau ditolaknya sebuah hipotesis apabila signifikansi di bawah atau sama dengan 0,01 ( $p<0,01)$ (Sugiyono, 2013). Pada penelitian ini probabilitas (p), yaitu $0,002<0,01$. Jadi, dapat disimpulkan bahwa hipotesis diterima, dengan demikian terdapat hubungan antara kematangan emosi dengan kepuasan pernikahan pada wanita yang bekerja, semakin tinggi kematangan emosi yang dimiliki oleh wanita bekerja maka semakin baik pula kepuasan pernikahannya. Berdasarkan hasil analisis product moment, diperoleh hasil koefisien korelasi sebesar 0,313.

Selain itu hasil kategorisasi menunjukkan bahwa istri yang bekerja yang menjadi subjek penelitian ini secara keseluruhan subjek pada skala kepuasan pernikahan cenderung rendah (98,8\%), maka dapat diartikan bahwa sebagian besar wanita bekerja pada penelitian ini memiliki kepuasan pernikahan yang rendah. Sedangkan kematangan emosi mereka secara keseluruhan cenderung tinggi (98,8\%). Artinya, istri yang bekerja yang menjadi subjek penelitian ini memiliki kematangan emosi yang tinggi.

Hasil penelitian ini menunjukkan bahwa hipotesis dalam penelitian ini diterima. Semakin tinggi kematangan emosi maka semakin tinggi pula kepuasaan pernikahan, sebaliknya semakin rendah kematangan emosi maka semakin rendah pula kepuasaan pernikahan pada wanita bekerja. Widuri (2014) dan Nurpratiwi (2010) menunjukkan bahwa tingkat kematangan emosi yang dimiliki seseorang dapat mempengaruhi kepuasan pernikahannya. Davidoff (1991), kepuasan pernikahan dapat dipengaruhi dengan hubungan yang terjalin mesra dan damai bersama pasangan. Kemesraan dan kedamaian dapat terwuud dengan adanya kematangan emosi. Blood dan Blood (Rismawati, 2009) menambahkan, seseorang yang matang secara emosional memiliki kemampuan dalam 
menjalin dan mempertahankan hubungan personal.kematangan emosi akan menghasilkan kepuasan pernikahan.

Kematangan emosi yang dimiliki oleh istri yang bekerja dapat membantu mengatasi perselisihan di rumah tangga yang muncul akibat dari respon emosi yang buruk sehingga, kematangan emosi menjadi salah satu faktor untuk mencapai kepuasan pernikahan. Seseorang yang memiliki kematangan emosi tergambar dari kemampuan memahami diri sendiri dan orang lain, tidak implusif, kemampuan dalam mengontrol emosi, kemampuan dalam berpikir objektif dan memiliki tanggung jawab (Walgito, 2004).

Istri yang matang emosinya akan mempunyai tanggung jawab yang baik (Walgito, 2004). Istri yang bekerja dikatakan bertanggung jawab apabila melaksanakan tugasnya dalam kondisi apapun. Meskipun istri sudah lelah bekerja dan mengalami kondisi psikis yang buruk, namun kondisi tersebut tidak membuatnya untuk tidak melaksanakan apa yang telah menjadi tanggung jawabnya kepada keluarga. Istri yang bekerja akan berusaha untuk tetap melaksanakan tugasnya, karena mereka sadar bahwa ini telah menjadi risikonya. Tanggung jawab terhadap keluarga yang terlaksana dengan baik tidak akan menimbulkan pertengkaran dengan pasangan sehingga istri yang bekerja merasakan kenyamanan akan peran yang dijalaninya. Kenyamanan dalam peran yang istri rasakan ini menggambarkan terciptanya kepuasan pernikahan. Hal ini sesuai dengan pernyataan Olson \& Fower (1989), bagaimana perasaan dan sikap individu mengenai peran pernikahan dan keluarga merupakan aspek dari kepuasan pernikahan.

Selain itu, istri yang mempunyai kematangan emosi akan memiliki kemampuan berpikir secara baik sehingga dapat menempatkan persoalan secara objektif (Annisa dan Handayani, 2012). istri yang mampu berpikir objektif akan dapat menerima dan berempati dengan kesalahan yang dilakukan oleh pasangan dan meyakini bahwa setiap perilaku ada alasannya. Kemampuan tersebut menciptakan perasaan nyaman, damai, dimengerti dan dihargai dalam hubungan sebagai suami istri. Perasaan tersebut dapat memperlancar komunikasi bersama pasangan sehingga pasangan menjadi terbuka, jujur dan saling percaya. Kenyamaan yang dirasakan oleh pasangan suami istri dalam memberi dan menerima informasi merupakan tanda terciptanya kepuasan pernikahan (Olson \& Fowers, 1989).

Hasil penelitian ini menunjukkan bahwa variabel kematangan emosi memberikan kontribusi terhadap variabel kepuasan pernikahan sebesar 9,8\% dan 81,2\% dipengaruhi oleh faktor-faktor lain yang tidak diteliti dalam penelitian ini. Sangat rendahnya 
sumbangan efektif kematangan emosi terhadap kepuasan pernikahan menandakan bahwa kematangan emosi tidak memiliki kontribusi yang besar terhadap kepuasan pernikahan. Beberapa faktor yang mungkin saja memiliki kontribusi yang lebih besar terhadap kepuasan pernikahan adalah kemampuan paangan suami istri dalam menjalankan peran rumah tangga, kehadiran anak, Empati, dan sosial ekonomi.

Kemampuan pasangan suami istri untuk menjalani peran dalam rumah angga akan berpengaruh pada kepuasan pernikahan yang dirasakan (Paputungan, dkk., 2012). Kehadiran anak, menjelaskan bahwa pasangan yang memiliki anak pada umumnya merasakaan kepuasan dan kebahagiaan dalam kehidupan pernikahan dibandingkan pasangan yang tidak memiliki anak (Agnesty, 2015). Empati merupakan kemampuan pasangan suami istri dalam menyadari, memahami, dan menghargai perasaan orang lain akan mengakibatkan konflik rendah. Hal ini dikarenakan ada kesediaan diri untuk tidak berfokus pada pikiran dan perasaan sendiri melainkan juga pada jalan pikiran dan perasaan pasangan untuk memahaminya. Kondisi ini akan menciptakan perasaan puas dalam kehidupan berumah tangga (Cramer \& Jowett, 2010). Kondisi sosial ekonomi juga dapat mempengaruhi kepuasan pernikahan. Keadaan sosial ekonomi terkait dengan seberapa besar penghasilan pasangan menikah. Hal ini sejalan dengan penelitian Dakin dan Wampler (dalam Istiqamah, 2015) mengatakan bahwa penghasilan pasangan mempengaruhi kepuasan pernikahan.

Hasil kategorisasi menunjukkan bahwa istri yang bekerja memiliki kepuasan pernikahan yang rendah, namun mereka memiliki kematangan emosi yang tinggi. hal ini menunjukkan bahwa kematangan emosi bukan merupakan prediktor yang baik dalam kepuasan pernikahan. Meskipun demikian kondisi istri yang bekerja dengan segala tuntutan dan tanggungjawab serta permasalahan dapat melatih istri dalam mengendalikan emosi sehingga mereka cenderung memiliki kematangan emosi yang tinggi.

\section{E. SIMPULAN}

Berdasarkan hasil penelitian dan pembahasan dalam penelitian ini, dapat ditarik kesimpulan bahwa terdapat hubungan positif antara kematangan emosi dan kepuasan pernikahan pada wanita bekerja, semakin tinggi kematangan emosi maka semakin tinggi kepuasan pernikahan pada wanita bekerja, sebaliknya semakin rendah kematangan emosi maka semakin rendah pula kepuasan pada wanita bekerja. 


\section{DAFTAR REFERENSI}

Agnesty, R. (2015). Hubungan Kualitas Komunikasi dengan Kepuasan Pernikahan Pada Pasangan Suami Istri. Pekanbaru: Universitas Islam Negeri Suska Riau.

Ananda, M. R. (2013). Self-esteem Antara Ibu Rumah Tangga yang Bekerja dengan yang Tidak Bekerja. Jurnal Online Psikologi, 41- 54.

Cramer, D \& Jowet, S. (2010). Perceived Empathy, Accurate Empathy and Relationship Satisfaction in Heterosexual Couple. Journal of Social and Personal Relationship. 327349.

Davidoff, L.L. (1991). Psikologi Suatu Pengantar (edisi ke-2) Jilid 2. Jakarta: Penerbit Erlangga.

Estuti, W. T. (2013). Dampak Perceraian Orang Tua Terhadap Tingkat Kematangan Emosi Anak Kasus Pada 3 Siswa Kelas VII Smp Negeri2 Pekuncen Banyumas Tahun Ajaran 2012/2013. SKRIPSI. Fakultas Ilmu Pendidikan Universitas Negeri Semarang.

Fowers, B. J. \& Olson, D. H. (1989). ENRICH Marital Inventory: A Discriminant Validity \& Cross-Validity Assessment. Journal of Marital and Family Therapy,15 (1), 65-79.

(1993). Enrich Marital Scale: A Brief Research And Clinical Tool. Journey of Family Psychology, 7 (2), 176-185.

Nurpratiwi, A. (2010). Pengaruh Kematangan Emosi dan Usia Saat Menikah Terhadap Kepuasan Pernikahan Pada Dewasa Awal. Jakarta. UIN Syarif Hidayatullah.

Olson, D. H., Defrain, J \& Skogrand, L. (2010). Marriage Family: Intimacy, Diversity, and Strengths. Edisi Ketujuh. New York: Mc Graw Hill.

Paputungan, F., Lusy, A, A., \& Ari, P. (2012). Kepuasan Pernikahan Suami Yang Memiliki Istri Berkarir. Universitas Brawijaya Malang.

Rahmiati, A. (2010). Pengaruh Emotional Expressivity Pasangan Suami Istri Terhadap Kepuasan Pernikahan. Universitas Islam Sultan Syarif Kasim Hidayatullah.

Ratnawati, D. (2008). Dampak Peran Ganda Pada Ibu Bekerja. SKRIPSI. Fakultas Psikologi Universitas Katolik Soegijapranata.

Rismawati, S. (2008). Hubungan Kematangan Emosi dengan Kepuasan Pernikahan (Studi Deskriptif Pada Kelompok Istri Bekerja dan Kelompok Istri Tidak Bekerja). Depok: Universitas Indonesia.

Stefani., Pudjibudojo, J. K,\& Prihanto, F. X.S. (2000) . Hubungan Antara Peran Gender Dan Persepsi Terhadap Dukungan Suami Dengan Fear Of Succes Pada Wanita Karir. Indonesian Psychological Journal Vol. 16 No.1 51-73

Sugiyono. (2013). Statiska untuk penelitian. Bandung: Alfabeta. 
Walgito, B. (2004). Bimbingan dan Konseling Perkawinan. Yogyakarta: Andi Offset.

Widuri, N. (2014). Hubungan Kematangan Emosi dengan Kebahagiaan Pernikahan Ditinaju dari Lama Menikah Pada Istri. Yogyakarta: UIN SUKA. 